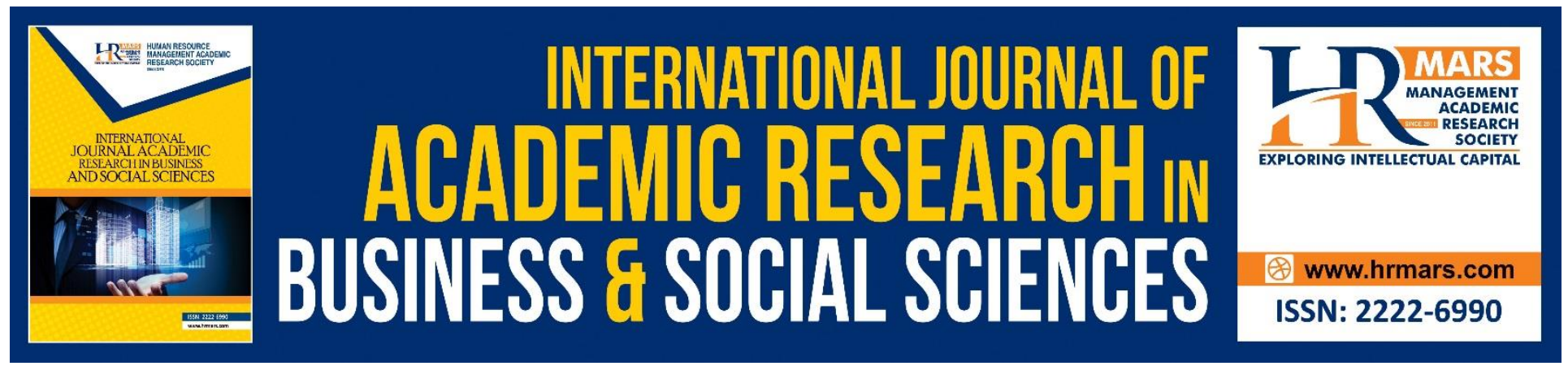

\title{
Linking University Reputation, Motivation, Organizational Climate and Job Satisfaction: A Proposed Framework
}

Abdulrasheed Abdullah Aminullah, Mohd Faizal Bin Mohd Isa, Wan Shakizah Wan Mohd Noor, Fadzli Shah AbdulAzeez

To Link this Article: http://dx.doi.org/10.6007/IJARBSS/v9-i1/5473

DOI: $\quad 10.6007 /$ IJARBSS/v9-i1/5473

Received: 18 Dec 2018, Revised: 21 Jan 2019, Accepted: 29 Jan 2019

Published Online: 18 Feb 2019

In-Text Citation: (Aminullah, Isa, Noor, \& AbdulAzeez, 2019)

To Cite this Article: Aminullah, A. A., Isa, M. F. B. M., Noor, W. S. W. M., \& AbdulAzeez, F. S. (2019). Linking University Reputation, Motivation, Organizational Climate and Job Satisfaction: A Proposed Framework. International Journal of Academic Research in Business and Social Sciences, 9(1), 698-709.

Copyright: (C) 2019 The Author(s)

Published by Human Resource Management Academic Research Society (www.hrmars.com)

This article is published under the Creative Commons Attribution (CC BY 4.0) license. Anyone may reproduce, distribute, translate and create derivative works of this article (for both commercial and non-commercial purposes), subject to full attribution to the original publication and authors. The full terms of this license may be seen

at: http://creativecommons.org/licences/by/4.0/legalcode

Vol. 9, No. 1, 2019, Pg. 698 - 709

http://hrmars.com/index.php/pages/detail/IJARBSS

JOURNAL HOMEPAGE

Full Terms \& Conditions of access and use can be found at http://hrmars.com/index.php/pages/detail/publication-ethics 


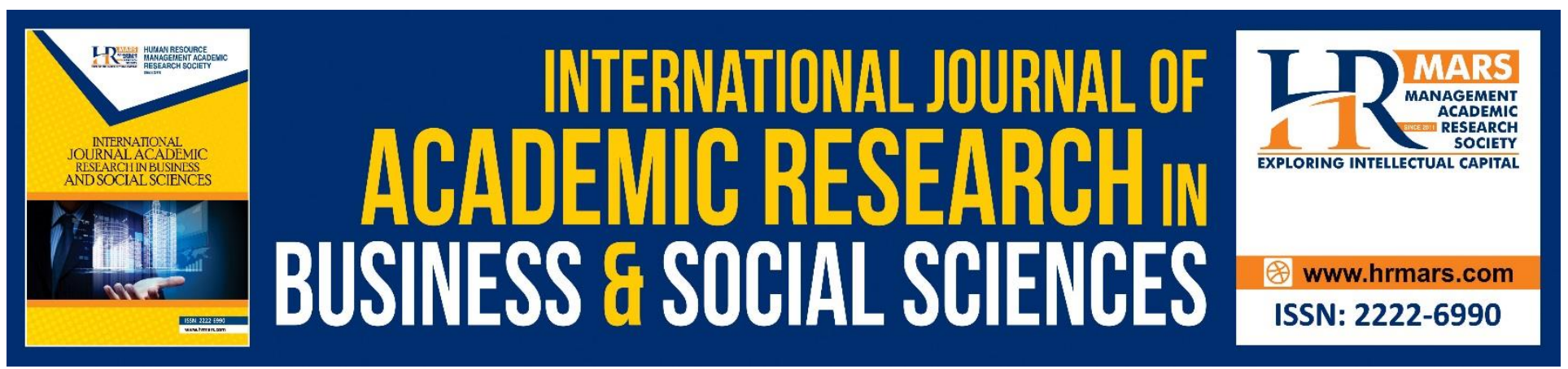

\title{
Linking University Reputation, Motivation, Organizational Climate and Job Satisfaction: A Proposed Framework
}

\author{
Abdulrasheed Abdullah Aminullah
}

School of Business Management, Universiti Utara Malaysia, Malaysia Email: alfarasheed@yahoo.com

Mohd Faizal Bin Mohd Isa

School of Business Management, Universiti Utara Malaysia, Malaysia Email:m.faizal@uum.my

\section{Wan Shakizah Wan Mohd Noor}

School of Business Management, Universiti Utara Malaysia, Malaysia Email: shakizah@uum.edu.my

\section{AbdulAzeez, Fadzli Shah}

School of Business Management, Universiti Utara Malaysia, Sintok Malaysia

Email: f.shah@uum.edu.my

\begin{abstract}
Consistently nurturing job satisfaction remains a cardinal principle of most organizations. This study is designed to test the effect of both intrinsic and extrinsic motivation, organizational climate, university reputation on job satisfaction in some public universities. It is widely acknowledged that the role of motivation towards ensuring employees satisfaction is not in any doubt. Equally when complimented by a supporting environment and enhanced by requisite reputation, the issue of employee job satisfaction is amicably resolved. This paper proposes a model that links the moderating role of university reputation between motivation, organizational climate and job satisfaction. It includes supporting literatures for the proposed model in other to contextualise the study. Its contribution to knowledge rest on the fact that university reputation affects various aspects of human behaviour as well as shows the relevance and importance of reputation towards developing a healthy competitive advantage. Apart from that, university reputation is also considered and shown
\end{abstract}


INTERNATIONAL JOURNAL OF ACADEMIC RESEARCH IN BUSINESS AND SOCIAL SCIENCES

Vol. 9, No. 1, Jan, 2019, E-ISSN: 2222-6990 @ 2019 HRMARS

as being pivotal for conducting future planning and recruitment thereby enhancing academic's job satisfaction.

Keywords: Intrinsic And Extrinsic Motivation, Organizational Climate, University Reputation, Job Satisfaction.

\section{INTRODUCTION}

In a $21^{\text {st }}$ century educational setup, university academic staff constitutes the driving force of academic excellence (Acikgoz, 2019). This is because university lecturers are regarded as scientific workers who carry out independent researchers that is critical for their institutions to remain the stronghold of ideologies and therefore their work is considered to be very stressful (Dai, Zhuang, \& Huan, 2019). Their work is generally regarded to be influenced by many factors among which are motivation: intrinsic and extrinsic, job satisfaction and organizational climate (Carapinha, McCracken, Warner, Hill, \& Reede, 2017). According to Zhao, Ghiselli, Law, and Ma (2016) job satisfaction is one of the most widely researched topics which always gains the attentions of researchers irrespective of discipline and more attention needed to be paid to academic staff job satisfaction because of the enormous influence it has on lecturers professional and psychological well-being (Kjeldsen \& Hansen, 2016). Therefore the growing number of researches on this topic points to its overwhelming significance. Moreover, motivation triggers and projects academic staff individual convictions on why they are carrying out their job and as well as about their own self esteem. In fact studies are replete with examples which indicates that job satisfaction plays a crucial role in the life of an academic staff because, when academic staff are satisfied with their job they tend to place more significant emphasis on their job and students success (Salehi \& Taghavi, 2016). Furthermore, it also impacts on the quality on the work produced by the academic staff (Amin, 2015). Considering the fact that most academic staff carry out their work in highly challenging and complex environmental climate, like teaching, conducting research and guiding students which does have effect on the level of their job satisfaction (Hayday, 2017). Organizational climate explains the relationship which exist between organizations and individuals (Ismail \& Abd Razak, 2016). Meanwhile university reputation signifies not only how dependable and straightforward educational institutions are in creating constructive relationship with others in the external environments, but also about the many activities an institution embarks upon so as to form an external image (Eser Telci \& Kantur, 2014). Academic staff that are satisfied with their job and climate often turn out to be the most committed, resourceful and satisfied which is indispensable for educational institutions to achieve set goals and objectives (Judge, Weiss, Kammeyer-Mueller, \& Hulin, 2017).

Previous literatures has shown that job satisfaction can be influenced by several factors among which are motivation and organizational climate and university reputation. Numerous studies have also indicated that attitudinal variables such as job satisfaction is positively associated with motivation and organizational climate (Eliophotou-menon \& Ioannou, 2016). Extensive review of literature has revealed that limited studies has examined the effects of motivation: intrinsic and extrinsic, organizational climate on job satisfaction in the educational sector. Not only were the plethora of past studies which conducted investigations using these variable located in western countries, very few of them was done in Asia and even Malaysia. Therefore this study intends to contribute to the body of knowledge by attempting to provide some credible ideals for stakeholders in higher 
INTERNATIONAL JOURNAL OF ACADEMIC RESEARCH IN BUSINESS AND SOCIAL SCIENCES

Vol. 9, No. 1, Jan, 2019, E-ISSN: 2222-6990 @ 2019 HRMARS

educational institutions by making linkage with the aforementioned variables in Malaysian higher educational institutions. Next is the review of literatures on variables.

\section{LITERATURE REVIEW}

\section{Higher Education in Malaysia}

The aim and the plan for designing higher educational intuitions in Malaysia is to absorb all the needs and demands of higher education in Malaysia (Hesampour et al., 2017). As documented by studymalaysia.com, Malaysia is having well over 500 tertiary educational institutions of higher learning who provide educational and learning facilities to students from home and abroad. These include some 21 public universities, about 53 private universities including some six foreign university branch campuses. In addition to that, it is also documented that Malaysia is also home to some 403 private colleges as well as 30 polytechnics and 73 public community colleges as far back as 2011 . As enshrined in the Malaysian higher education act, higher education in Malaysia is regulated by the ministry of higher education which was established the Malaysia qualification framework and the Malaysian qualification agency which is saddled with the task of conducting quality research, providing quality teaching so as to meet with requirement of the national accreditation standard (Stankovska, Angelkoska, Osmani, \& Grncarovska, 2017). These erudite government regulatory agencies in Malaysia has become very instrumental in effecting systematic reviews and positive changes into various courses and programmes based on international world best practice and standards (Yvonne, Rahman, \& Long, 2014).

\section{Job Satisfaction}

The concept of job satisfaction is defined as a pleasurable or positive emotional state resulting from the appraisal of job he or she experiences (Hanaysha \& Tahir, 2016). Similarly, Zopiatis, Constanti, and Theocharous (2014) refers to job satisfaction as an evaluative state that expresses contentment with positive feelings about one's job. Likewise, Waqas (2014) considered job satisfaction as a positive (or negative) evaluative judgement one makes about one's job or job situation. Based on the definition given by previous scholars and in line with the definition given by Fung, Ahmad, and Omar (2014), this study defines academic job satisfaction as the general and specific positive feelings of academic staff in the universities context, related to the need they expect to be achieved by the job they perform.

\section{Job Satisfaction and Intrinsic Motivation}

Intrinsic motivation is described as the feelings which is derived without any obvious external rewards (Cerasoli, Nicklin, \& Ford, 2014). In this context, intrinsic motivation refers to the inherent, rational ability of an individual to engage ones interest and use ones capacity, and in so doing to achieve ideal changes (Mekler, Brühlmann, Opwis, \& Tuch, 2013). According to Mekler, Brühlmann, Tuch, and Opwis (2015), people are said to be intrinsically motivated when they desire attention, satisfaction of interest, self-expression, or personal fulfilment at work.

Empirically intrinsic motivation has been shown to have positive relationship with job satisfaction (Masvaure, Ruggunan, \& Maharaj, 2014; Cerasoli 2014; Araslı, Daşkın, \& Saydam, 2014; DePasque \& Tricomi, 2015; Zhao 2016). On the other hand quite a few studies also demonstrated negative 
INTERNATIONAL JOURNAL OF ACADEMIC RESEARCH IN BUSINESS AND SOCIAL SCIENCES

Vol. 9, No. 1, Jan, 2019, E-ISSN: 2222-6990 @ 2019 HRMARS

relationship ( Lambrou, Kontodimopoulos, and Niakas (2010) and (Du Preez, 2013). Therefore it is proposed that,

Proposition 1. Intrinsic motivation is positively associated with job satisfaction.

\section{Job satisfaction and Extrinsic Motivation}

Existing literatures have demonstrated that extrinsic motivation is effective in influencing and shaping the job satisfaction of employees (Mafini \& Dlodlo, 2014; Mafini, C., \& Dlodlo, 2014;Belle \& Cantarelli, 2015; Kappel, 2012; Gagné 2015).

Many studies in the past have attempted to identify the various predictors of job satisfaction. And according to Wu and Lu (2013) extrinsic motivation have been have demonstrated to be one of the most important determinants. More so, extrinsic motivation does have a positive relationship with job satisfaction.(Benedetti, Diefendorff, Gabriel, \& Chandler, 2015; Hee, Hayati, \& Kamaludin, 2016;Li \& Wang, 2016). However extrinsic motivation also recorded negative relationship with job satisfaction at alternate times (Khalatbari, Ghorbanshiroudi, \& Firouzbakhsh, 2013; Li, Hu, Zhou, He, Fan, Liu, and Sun, 2014; Cho, \& Perry, 2012).

Proposition 2: Extrinsic motivation is positively associated with job satisfaction.

\section{Organizational Climate and Job Satisfaction}

Organizational climate was described by (Tsai, 2014) as organizational climate as the collective insight concerning the actual situation of events within the organization. Avram, lonescu, and Mincu (2015) also sees organizational climate as a set of attributes specific to a particular organization that may be induced from the way that organization deals with its members and its environment. In the context of an educational setting, organizational climate is a circumstance representing a school's ability to act excellently and competently and it will be safe to assume that long term improvement and effectiveness will not be achieved in the absence of a complimentary school environment. Even though may possess some common features of climate but does not captures the totality of the concept. Most scholars consider Organizational climate to be a concept that sticks with organization for a long time given the continuity nature of most organizations. They refer to climate conditions within organizations as being phenomenological, because climate is what happens in the external environments from the employees point of view but it those have a an internal cognitive effect on the employee that works in the organization individual.

In the Malaysian context, a study conducted by Ghavifekr, and Pillai, (2016) and done in Penampang, Sabah, on 245 tutors from 6 schools, there was significant relationship between school organizational climate and job satisfaction. The result of the study is consistent with an earlier study conducted by Brimhall, Lizano, and Mor Barak (2014) on 363 employees of a large urban public child welfare agency in the western United States. Results indicated that leader-member exchange and diversity climate have a positive effect on job satisfaction through inclusion, and that a positive organizational climate can lower intention to leave through both inclusion and job satisfaction. Findings illustrate how organizational climates of diversity and inclusion affect both job satisfaction and intention to leave.

Proposition 3: Organizational Climate is positively related to job satisfaction. 


\section{University Reputation and Job Satisfaction}

The reputation of educational institutions for both students and academics staff has been a matter of crucial relevance since past decades. literature evidence exist in abundance to show the relevance and importance of reputation towards nurturing a healthy competitive advantage such as (Gotsi \& Wilson, 2001; Gardberg \& Fombrun, 2002; Inglis, Morley, \& Sammut, 2006). According to (Kay, 1993), university reputation plays a very crucial role in determining organizational achievement. In institutions of higher education, reputation is considered as an overall replication of the institution' worth, effect, and dependability (van Vught, 2008). Hence reputation is considered as a cherished and concrete asset (Caruana \& Ewing, 2010; Maden, Arıkan, Telci, \& Kantur, 2012;Sung \& Yang, 2009). Furthermore, reputation does has a substantial influence on employees or students especially when they are faced with the choice of making a selection whenever they want to secure admission into a university and for staff when they want to identify with integrity, worth and reputation (Hon \& Brunner, 2002). Some other authors are of the opinion that reputation does have some bearing on trust and employee satisfaction ( Gefen, Karahanna, \& Straub, 2003;Kim, Ferrin, \& Rao, 2008).

Existing study by (Helm, 2013) has demonstrated that employees seek to work in institution with good integrity and reputation. It is safe and reasonable to infer that employees tend to be satisfied with their work if the institution they work in possess good or high reputation.

Supporting this arguments is the result of a Pakistani study by Gul, (2014) on 150 employees from the Islamia University, Quaid-e-Azam Medical College which showed that there is positive and significant relationship among reputation, employee satisfaction, trust and customer loyalty. In a more recent study by Yang, Yaacob, and (2015), among 309 middle level managers of randomly selected small and medium sized enterprises in Hebei, China. The result indicates positive relationship between corporate reputation and job satisfaction is supported. Proposition 4: University reputation Moderates the relationship between motivation, organizational climate and job satisfaction. 
INTERNATIONAL JOURNAL OF ACADEMIC RESEARCH IN BUSINESS AND SOCIAL SCIENCES

\section{CONCEPTUAL FRAMEWORK}

Independent Variables

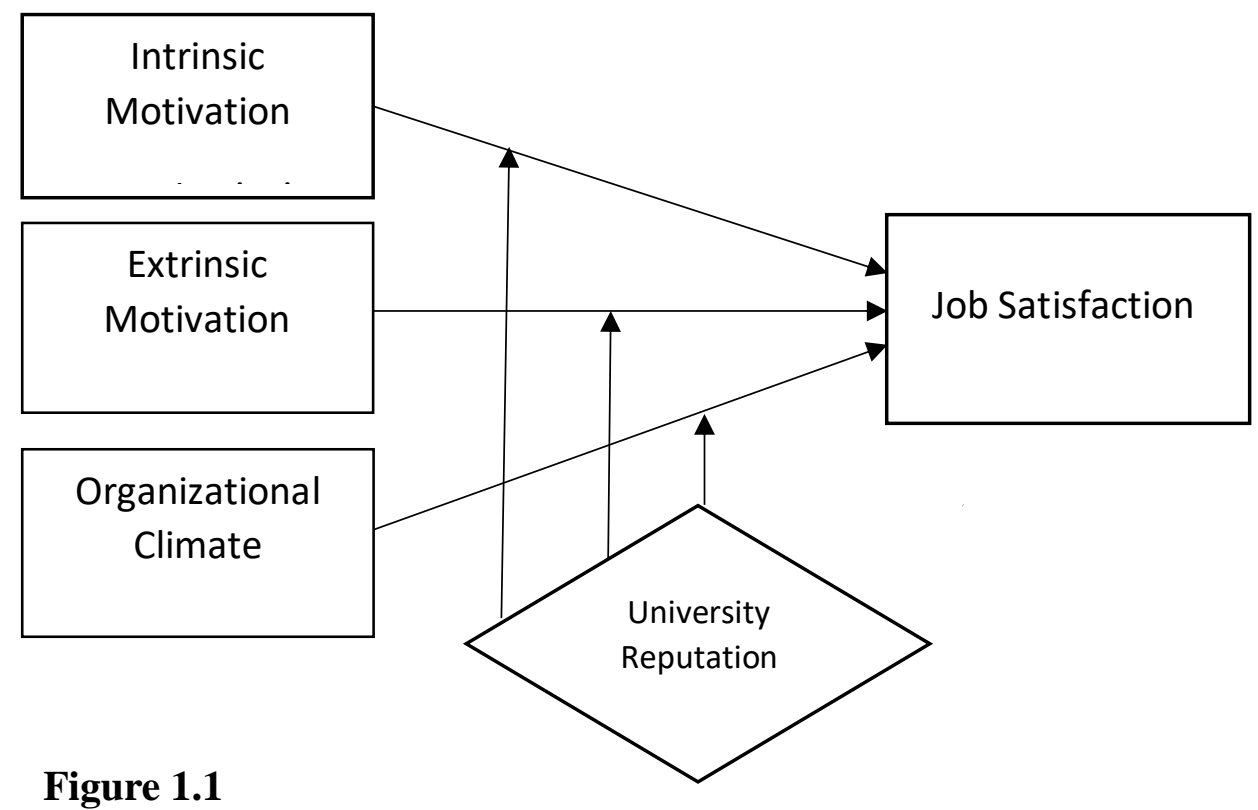

\section{Proposed model}

\section{Moderator}

Drawing from this discussion, a conceptual framework was proposed, as illustrated in figure 1. It shows that motivation, (intrinsic and extrinsic), organizational climate have a positive and significant relationship with university reputation and in turn enhances job satisfaction.

\section{CONCLUSION}

Previously, a review of literature has revealed that both motivation and organizational climate have been instrumental in enhancing employee job satisfaction especially among non-educational institutions. The proposed research framework further posits that academic staff which consist of tutors, lecturers and professors that teach in public universities are more likely to be satisfied with their job if their job if they are sufficiently motivated given an enabling and conducive working environment. Theoretically, the paper could deliver theoretical inferences by giving additional empirical evidence in the domain of job satisfaction. It could contribute to the body of knowledge by substantiating the existence of the significant direct and indirect influence of intrinsic motivation and organizational climate through the variable of university reputation. We conclude that the research framework proposes that university reputation moderates the relationship between motivation, organizational climate and job satisfaction. This paper will contribute to knowledge in the sense that the management of universities could promote laws, policies and schemes that improve the welfare and work conditions of lecturers that can lead to positive work outcomes (Issah 2013). For example, management of the universities might establish staff welfare support schemes to help boost the volume of discussions, symposiums, departmental and faculty consultations aimed at investigating 
INTERNATIONAL JOURNAL OF ACADEMIC RESEARCH IN BUSINESS AND SOCIAL SCIENCES

Vol. 9, No. 1, Jan, 2019, E-ISSN: 2222-6990 @ 2019 HRMARS

possible factors or reasons that might cause loss on motivation and confidence among staff in the entire universities understudy.

\section{REFERENCES}

Acikgoz, Y. (2019). Employee recruitment and job search: Towards a multi-level integration. Human Resource Management Review. https://doi.org/10.1016/j.hrmr.2018.02.009

Amin, M. (2015). Relationship between job satisfaction, working conditions, motivation of teachers to teach and job performance of teachers in MTs, Serang, Banten. Journal of Management and Sustainability, 5(3), 141-154. https://doi.org/10.5539/jms.v5n3p141

Araslı, H., Daşkın, M., \& Saydam, S. (2014). Polychronicity and intrinsic motivation as dispositional determinants on hotel frontline employees' job satisfaction: Do control variables make a difference? Procedia - Social and Behavioral Sciences, 109, 1395-1405. https://doi.org/10.1016/j.sbspro.2013.12.643

Avram, E., Ionescu, D., \& Mincu, C. L. (2015). Perceived safety climate and organizational trust: the mediator role of job satisfaction. Procedia - Social and Behavioral Sciences, 187, 679-684. https://doi.org/10.1016/j.sbspro.2015.03.126

Belle, N., \& Cantarelli, P. (2015). Monetary incentives, motivation, and job effort in the public sector: An experimental study with italian government executives. Review of Public Personnel Administration, 35(2), 99-123. https://doi.org/10.1177/0734371X13520460

Benedetti, A. A., Diefendorff, J. M., Gabriel, A. S., \& Chandler, M. M. (2015). The effects of intrinsic and extrinsic sources of motivation on well-being depend on time of day: The moderating effects of workday accumulation. Journal of Vocational Behavior, 88, 38-46. https://doi.org/10.1016/j.jvb.2015.02.009

Brimhall, K. C., Lizano, E. L., \& Mor Barak, M. E. (2014). The mediating role of inclusion: A longitudinal study of the effects of leader-member exchange and diversity climate on job satisfaction and intention to leave among child welfare workers. Children and Youth Services Review, 40, 79-88. https://doi.org/10.1016/j.childyouth.2014.03.003

Carapinha, R., McCracken, C. M., Warner, E. T., Hill, E. V., \& Reede, J. Y. (2017). Organizational context and female faculty's perception of the climate for women in academic medicine. Journal of Women's Health. https://doi.org/10.1089/jwh.2016.6020

Caruana, A., \& Ewing, M. T. (2010). How corporate reputation, quality, and value influence online loyalty. Journal of Business Research, 63(9-10), 1103-1110. https://doi.org/10.1016/j.jbusres.2009.04.030

Cerasoli, C. P., Nicklin, J. M., \& Ford, M. T. (2014). Intrinsic motivation and extrinsic incentives jointly predict performance: A 40-year meta-analysis. Psychological Bulletin, 140(4), 980-1008. https://doi.org/10.1037/a0035661

Cho, Y. J., \& Perry, J. L. (2012). Intrinsic motivation and employee attitudes role of managerial trustworthiness, goal directedness, and extrinsic reward expectancy. Review of Public Personnel Administration, 32(4), 382-406. https://doi.org/10.1177/0734371X11421495

Dai, Y. De, Zhuang, W. L., \& Huan, T. C. (2019). Engage or quit? The moderating role of abusive supervision between resilience, intention to leave and work engagement. Tourism Management. https://doi.org/10.1016/j.tourman.2018.07.014 
INTERNATIONAL JOURNAL OF ACADEMIC RESEARCH IN BUSINESS AND SOCIAL SCIENCES

Vol. 9, No. 1, Jan, 2019, E-ISSN: 2222-6990 @ 2019 HRMARS

DePasque, S., \& Tricomi, E. (2015). Effects of intrinsic motivation on feedback processing during learning. Neurolmage, 119, 175-186. https://doi.org/10.1016/j.neuroimage.2015.06.046

Eliophotou-menon, M., \& Ioannou, A. (2016). The link between transformational leadership and teachers' job satisfaction, commitment, motivation to learn, and trust in the leader. Academy of Educational Leadership Journal, 20(3), 12-23.

Eser Telci, E., \& Kantur, D. (2014). University reputation: Scale development and validation. Bogazici Journal, 28(2), 49-73.

Fung, N. S., Ahmad, A., \& Omar, Z. (2014). Role of work-family enrichment in improving job satisfaction. American Journal of Applied Sciences, 11(1), 96-104. https://doi.org/10.3844/ajassp.2014.96.104

Gagné, M., Forest, J., Vansteenkiste, M., Crevier-Braud, L., van den Broeck, A., Aspeli, A. K., ... Westbye, C. (2015). The multidimensional work motivation scale: Validation evidence in seven languages and nine countries. European Journal of Work and Organizational Psychology, 24(2), 178-196. https://doi.org/10.1080/1359432X.2013.877892

Gardberg, N. a, \& Fombrun, C. J. (2002). The global reputation quotient project: First steps towards a cross-nationally valid measure of corporate reputation. Corporate Reputation Review , 4(4), 303307. https://doi.org/10.1057/palgrave.crr.1540151

Gefen, D., Karahanna, E., \& Straub, D. W. (2003). Inexperience and experience with online stores: The importance of TAM and trust. IEEE Transactions on Engineering Management, 50(3), 307-321. https://doi.org/10.1109/TEM.2003.817277

Ghavifekr, S., \& Pillai, N. S. (2016). The relationship between school's organizational climate and teacher's job satisfaction: Malaysian experience. Asia Pacific Education Review, 17(1), 87-106. https://doi.org/10.1007/s12564-015-9411-8

Gotsi, M., \& Wilson, A. M. (2001). Corporate reputation: Seeking a definition. Corporate Communications: An International Journal, 6(1), 24-30. https://doi.org/10.1108/13563280110381189

Gul, R. (2014). The relationship between reputation, customer satisfaction, trust, and loyalty. Journal of Public Administration and Governance, 4(3), 368-387. https://doi.org/10.5296/ jpag.v4i3.6678

Hanaysha, J., \& Tahir, P. R. (2016). Examining the effects of employee empowerment, teamwork, and employee training on job satisfaction. In Procedia - Social and Behavioral Sciences (Vol. 219, pp. 272-282). https://doi.org/10.1016/j.sbspro.2016.05.016

Hayday, S. (2017). Questions to measure commitment and job satisfaction. The Institute for Employment Studies, 1-4.

Hee, O. C., Hayati, N., \& Kamaludin, B. (2016). Motivation and job performance among nurses in the private hospitals in malaysia. International Journal of Caring Sciences, 9(1), 1-342.

Helm, S. (2013). A matter of reputation and pride: associations between perceived external reputation, pride in membership, job satisfaction and turnover intentions. British Journal of Management, 24(4), 542-556. https://doi.org/10.1111/j.1467-8551.2012.00827.x

Hesampour, M., Akbari, M., Khanjani, N., Naghibzadeh-Tahami, A., Dehghan, A., Nabipour, A. R., ... Alipour, H. (2017). Job satisfaction among academic staff: A cross-sectional study. International Journal of Occupational Hygiene, 8(3), 129-135. 
INTERNATIONAL JOURNAL OF ACADEMIC RESEARCH IN BUSINESS AND SOCIAL SCIENCES

Vol. 9, No. 1, Jan, 2019, E-ISSN: 2222-6990 @ 2019 HRMARS

Hon, L., \& Brunner, B. (2002). Measuring public relationships among students and administrators at the university of Florida. Journal of Communication Management, 6(3), 227-238. https://doi.org/10.1108/13632540210807071

Inglis, R., Morley, C., \& Sammut, P. (2006). Corporate reputation and organisational performance: an Australian study. Managerial Auditing Journal, 21(9), 934-947. https://doi.org/10.1108/02686900610705028

Ismail, A., \& Abd Razak, M. R. (2016). A study on job satisfaction as a determinant of job motivation. Acta Universitatis Danubius: Oeconomica, 12(3), 30-44.

Judge, T. A., Weiss, H. M., Kammeyer-Mueller, J. D., \& Hulin, C. L. (2017). Job attitudes, job satisfaction, and job affect: A century of continuity and of change. Journal of Applied Psychology, 102(3), 356-374. https://doi.org/10.1037/apl0000181

Kappel, A. M. (2012). Generational cohort as a moderator of the relationship between extrinsic and intrinsic motivation and job satisfaction. proquest dissertations and theses (Doctoral dissertation, Walden University).

Kay, J. (1993). The structure of strategy. Business Strategy Review, 4(2), 17-37. https://doi.org/10.1111/j.1467-8616.1993.tb00049.x

Khalatbari, J., Ghorbanshiroudi, S., \& Firouzbakhsh, M. (2013). Correlation of job stress, job satisfaction, job motivation and burnout and feeling stress. In Procedia - Social and Behavioral Sciences (Vol. 84, pp. 860-863). https://doi.org/10.1016/j.sbspro.2013.06.662

Kim, D. J., Ferrin, D. L., \& Rao, H. R. (2008). A trust-based consumer decision-making model in electronic commerce: The role of trust, perceived risk, and their antecedents. Decision Support Systems, 44(2), 544-564. https://doi.org/10.1016/j.dss.2007.07.001

Kjeldsen, A. M., \& Hansen, J. R. (2016). Sector differences in the public service motivation-job satisfaction relationship: exploring the role of organizational characteristics. Review of Public Personnel Administration. https://doi.org/10.1177/0734371X16631605

Lambrou, P., Kontodimopoulos, N., \& Niakas, D. (2010). Motivation and job satisfaction among medical and nursing staff in a Cyprus public general hospital. Human Resources for Health, 8(1), 26. https://doi.org/10.1186/1478-4491-8-26

Li, L., Hu, H., Zhou, H., He, C., Fan, L., Liu, X., ... \& Sun, T. (2014). Work stress, work motivation and their effects on job satisfaction in community health workers: a cross-sectional survey in China. BMJ Open, 4(6), e004897. https://doi.org/10.1136/bmjopen-2014-004897

Li, M., \& Wang, Z. (2016). Emotional labour strategies as mediators of the relationship between public service motivation and job satisfaction in Chinese teachers. International Journal of Psychology, 51(3), 177-184. https://doi.org/10.1002/ijop.12114

Maden, C., Arıkan, E., Telci, E. E., \& Kantur, D. (2012). Linking corporate social responsibility to corporate reputation: A study on understanding behavioral consequences. In Procedia-Social and Behavioral Sciences (Vol. 58, pp. 655-664). https://doi.org/10.1016/j.sbspro.2012.09.1043

Mafini, C., \& Dlodlo, N. (2014). The relationship between extrinsic motivation, job satisfaction and life satisfaction amongst employees in a public organisation. SA Journal of Industrial Psychology, 40(1). https://doi.org/10.4102/sajip.v40i1.1166

Mafini, C., \& Dlodlo, N. (2014). The relationship between extrinsic motivation, job satisfaction and life satisfaction amongst employees in a public organisation. SA Journal of Industrial Psychology, 
INTERNATIONAL JOURNAL OF ACADEMIC RESEARCH IN BUSINESS AND SOCIAL SCIENCES

Vol. 9, No. 1, Jan, 2019, E-ISSN: 2222-6990 @ 2019 HRMARS

40(1), 1-13. https://doi.org/10.4102/sajip.v40i1.1166

Masvaure, P., Ruggunan, S., \& Maharaj, A. (2014). Work engagement, intrinsic motivation and job satisfaction among employees of a diamond mining company in Zimbabwe. Journal of Economics and Behavioral Studies, 6(6), 488-499.

Mekler, E. D., Brühlmann, F., Opwis, K., \& Tuch, A. N. (2013). Do points, levels and leaderboards harm intrinsic motivation? In Proceedings of the First International Conference on Gameful Design, Research, and Applications - Gamification '13 (pp. 66-73). https://doi.org/10.1145/2583008.2583017

Mekler, E. D., Brühlmann, F., Tuch, A. N., \& Opwis, K. (2015). Towards understanding the effects of individual gamification elements on intrinsic motivation and performance. Computers in Human Behavior, 1-10. https://doi.org/10.1016/j.chb.2015.08.048

Robyn, A., \& Du Preez, R. (2013). Intention to quit amongst generation $Y$ academics in higher education. $\quad\{S A\} \quad J o u r n a l$ of Industrial Psychology, 39(1), 1-14. https://doi.org/10.4102/sajip.v39i1.1106

Salehi, H., \& Taghavi, E. (2016). Teachers ' attitudes towards job satisfaction and their students ' beliefs and motivation. International Journal of Research Studies in Language Learning , 5(2), 1735. https://doi.org/10.5539/elt.v8n7p46

Stankovska, G., Angelkoska, S., Osmani, F., \& Grncarovska, S. P. (2017). Job motivation and job satisfaction among academic staff in higher education. In Current business and economics driven discourse and education: Perspectives from around the world (Vol. 15, pp. 159-167).

Sung, M., \& Yang, S. U. (2009). Student-university relationships and reputation: A study of the links between key factors fostering students' supportive behavioral intentions towards their university. Higher Education, 57(6), 787-811. https://doi.org/10.1007/s10734-008-9176-7

Tsai, C. L. (2014). The organizational climate and employees' job satisfaction in the terminal operation context of kaohsiung port. Asian Journal of Shipping and Logistics, 30(3), 373-392. https://doi.org/10.1016/j.ajsl.2014.12.007

van Vught, F. (2008). Mission diversity and reputation in higher education. Higher Education Policy, 21(2), 151-174. https://doi.org/10.1057/hep.2008.5

Waqas, A., Umair, B., Sattar, M. F., Abdullah, H. M., Hussain, I., Anjum, W., ... Arshad, R. (2014). Factors influencing job satisfaction and Its impact on job loyalty. International Journal of Learning \& Development, 4(2), 141-161. https://doi.org/10.5296/ijld.v4i2.6095

Wu, J., \& Lu, X. (2013). Effects of extrinsic and intrinsic motivators on using utilitarian, hedonic, and dual-purposed information systems: A Meta-Analysis. Journal of the Association for Information Systems, 14(3), 153-191.

Yang, L., Yaacob, Z., \& Teh, S. Y. (2015). The impact of corporate reputation on job satisfaction and financial performance: a study of small and medium sized enterprises in Hebei, China. Journal of Entrepreneurship \& Business, 3(1), 72-87.

Yvonne, W., Rahman, R. H. A., \& Long, C. S. (2014). Employee job satisfaction and job performance: A case study in a franchised retail - chain organization. Research Journal of Applied Sciences, Engineering and Technology, 8(17), 1875-1883. https://doi.org/10.19026/rjaset.8.1176

Zhao, X., Ghiselli, R., Law, R., \& Ma, J. (2016). Motivating frontline employees: Role of job characteristics in work and life satisfaction. Journal of Hospitality and Tourism Management, 27, 
INTERNATIONAL JOURNAL OF ACADEMIC RESEARCH IN BUSINESS AND SOCIAL SCIENCES

Vol. 9, No. 1, Jan, 2019, E-ISSN: 2222-6990 @ 2019 HRMARS

27-38. https://doi.org/10.1016/j.jhtm.2016.01.010

Zopiatis, A., Constanti, P., \& Theocharous, A. L. (2014). Job involvement, commitment, satisfaction and turnover: Evidence from hotel employees in Cyprus. Tourism Management, 41, 129-140. https://doi.org/10.1016/j.tourman.2013.09.013 